Article

\title{
New Directions in Youth and Young Adult Ministry Leadership: Where Have We Been and More Importantly Where Are We Headed?
}

\author{
Charlotte McCorquodale
}

Citation: McCorquodale, Charlotte. 2021. New Directions in Youth and Young Adult Ministry Leadership: Where Have We Been and More Importantly Where Are We Headed? Religions 12: 146. https:// doi.org/10.3390/rel12030146

Academic Editor: Arthur D. Canales

Received: 11 November 2020

Accepted: 8 February 2021

Published: 24 February 2021

Publisher's Note: MDPI stays neutral with regard to jurisdictional claims in published maps and institutional affiliations.

Copyright: (c) 2021 by the author. Licensee MDPI, Basel, Switzerland. This article is an open access article distributed under the terms and conditions of the Creative Commons Attribution (CC BY) license (https:// creativecommons.org/licenses/by/ $4.0 /)$.
Ministry Training Source, Metaire, LA 70001, USA; charlotte@ministrytrainingsource.org

\begin{abstract}
Catholic youth and young adult ministries have evolved vastly since they began in the 1930s. Throughout this ministry's history, a story of change is told. This article will explore three questions. First, what does the history of this ministry tell us about the future? This will include an examination of the past twenty years of research and trends on youth and young adult ministry and the ministry leaders serving them. Second, what are the current realities informing our new directions? Third, what are the new directions being called for regarding the Catholic Church's ministry to youth and young adults, and those that serve this ministry? Undoubtedly, Christus Vivit has shaped this conversation, and a large part of this direction includes a call for evangelization and accompaniment. Regardless, the key to moving in a new direction is understanding both the framework or characteristics for the pastoral ministry and the evolved role responsibilities of youth and young adult ministry leaders.
\end{abstract}

Keywords: youth ministry; young adult ministry; Generation Z; millennials; ministry leaders; National Dialogue; Christus Vivit; youth ministry leader research; diocesan youth and young adult ministry

\section{Introduction}

Catholic youth and young adult ministries have evolved vastly since they began in the 1930s. Throughout this ministry's history, a story of change is told, which continues today. Combining the declining religious affiliation rates ${ }^{1}$ for the younger generations with the impact that the pandemic is having on faith communities, it seems clear that ministry to youth and young adults is at yet another crossroads.

An examination of the following three poignant questions can help those in ministry leadership to chart a course for the uncertain future.

1. What does the history of this ministry and longitudinal research on youth and young adult ministry leaders tell us about the future?

2. What are the current realities informing our new directions?

3. What are the new directions being called for regarding the Church's ${ }^{2}$ ministry to youth and young adults, and those that serve this ministry?

Undoubtedly, Christus Vivit has shaped the answer to the last question. However, as each local church tries to interpret and apply it to their setting, what the ministry ultimately looks like is still uncertain and warrants reflection by each community. Those involved in this ministry know that a large part of this direction is a call for new, more, and unique ways to evangelize and accompany youth, young adults, and their families.

\footnotetext{
1 Saint Mary's Press in collaboration with the Center for Applied Research in the Apostolate (2017, p. 4).

2 The term "Church" with a capital " $\mathrm{C}$ " is used throughout this article to designate the Roman Catholic Church.
} 


\section{The Pendulum Swings of Catholic Youth and Young Adult Ministry}

In the 1930s, when the first Catholic Youth Organization (CYO) was formed by Bishop Bernard Sheil in Chicago as an athletic organization, it had the purpose of guiding young Catholic boys to live a Christian life. Bishop Sheil had observed rising criminal activity within his neighborhood and wanted to provide an experience of community and positive activity for the youth as an engaging alternative. ${ }^{3}$ Fast forward ninety years, and Pope Francis is identifying the same need to respond to the signs of the time regarding the Church's pastoral ministry with youth and young adults by proclaiming, " ... I have taken time to look at the reality of young people in today's world... I encourage communities to examine, respectfully and seriously, the situation of their young people, in order to find the most fitting ways to provide them pastoral care." 4

Catholic youth and young adult ministry in the United States has evolved in various ways since the early days of CYO. This journey has been marked by "social and cultural changes", as noted by Pope Francis in Christus Vivit. ${ }^{5}$ These changes, along with the ecclesial debates about the best pastoral approaches, have pushed and pulled the Church's pastoral ministry with the young in different ways, in different directions, and with different points of emphasis. It often feels like Catholic youth and young adult ministry has been swinging back and forth on a pendulum of pastoral approaches and emphases. Below is a review of some of those approaches.

Comprehensive Youth Ministry. The swing from Catholic Youth Organization (CYO) to comprehensive youth ministry began taking place in the seventies. In the early days, CYO was not focused on passing on faith but on helping young people to form community or groups, and live a Christian life, primarily through sports and social programs. As the popular culture began to change, becoming less Christian, a gradual evolution occurred. Institutions that at one time all worked together with families to form and support Christian young people began to lose their credibility or significance. ${ }^{6}$ These changes began to expose the many areas lacking in young people's lives, and a more comprehensive approach was needed in the Church's ministry efforts to form young Catholic Christians.

This comprehensive approach was presented in the 1976 document $A$ Vision of Youth Ministry. ${ }^{7}$ It set forth goals and principles to guide a unified approach to ministry with young people. This comprehensive approach identified eight components of ministry, with catechesis and evangelization being two of the eight. It pushed a swing towards a more programmatic model versus a group or community model.

Catechetical Methodology. Catechesis saw a pendulum swing from a focus on the question-and-answer approach of the Baltimore Catechism of the fifties and sixties, to an instructional-schooling approach in the seventies and eighties that included new learning models and methods. ${ }^{8}$ This swing saw a focus more on experiential learning models and a move away from a sole focus on doctrine. The challenges that catechesis faced went beyond methodology, and many continue still today. There have been many commonly known issues that the Church has faced in catechizing young people effectively, including finding competent catechists to teach, families not prioritizing catechesis or catechizing their own children, and adequate funding for catechetical staff and resources. ${ }^{9}$

In 2005, the National Study of Youth and Religion identified how unsuccessful the Church has been in its catechetical efforts. It found that young people, especially those who were Catholic, lacked greatly in not only their knowledge of faith but the language to articulate their beliefs. ${ }^{10}$ This research contributed to the pendulum swinging back to a

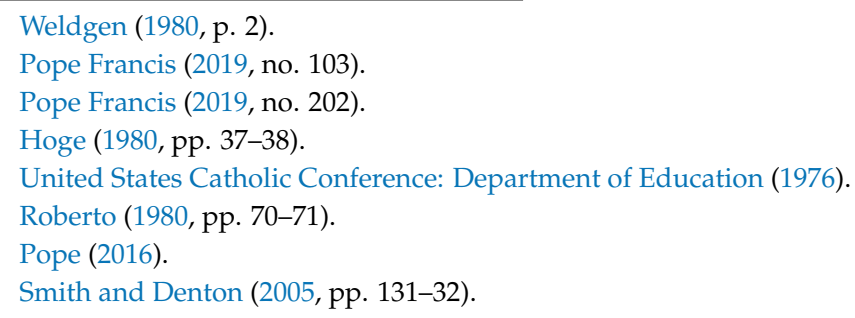


greater emphasis on doctrine and the Catechism of the Catholic Church (Catholic Church 2000) and having it guide catechetical efforts. One example of this swing was the development of the Doctrinal Elements of a Curriculum Framework for the Development of Catechetical Materials for Young People of High School Age by the United States Catholic Conference of Bishops. ${ }^{11}$ This was a swing back to a focus on the content of the catechesis versus the experience of it, including providing an encounter with God. Clearly, both are important, as seen in the next swing of the pendulum.

The New Evangelization. Concurrent to the swing from CYO to Youth Ministry, a swing in approaches to evangelization and catechesis occurred in 1983 with Pope John Paul II's call for a "new evangelization" to evangelize the baptized that had fallen away from the Church. ${ }^{12}$ The focus on the new evangelization would continue and expand through the papacy of Pope Benedict XVI and Pope Francis (Pontifical Council for the Promotion of the New Evangelization 2020). As a result of this new evangelization, various youth and young adult movements and organizations were created to respond, with ministries that offered opportunities to evangelize the baptized. These ministries, such as Lifeteen and Stubbenville Summer Youth Conferences, still flourish today.

Discipleship and Accompaniment. A focus on discipleship began in the nineties when the USCCB published two guiding documents: Sons and Daughters of Light (United States Catholic Conference Bishops 1996), for young adult ministry, and Renewing the Vision (United States Catholic Conference Bishops 1997), for youth ministry. These both had goals of forming young people as disciples of Jesus. However, this swing would not be fully realized as a priority until the Papacy of Pope Francis and his call for all Catholics to be missionary disciples. ${ }^{13}$

The current pendulum swing in Catholic youth and young adult ministry is the move from a programmatic approach towards one of accompanying youth and young adults as missionary disciples. In many ways, this is a swing back to a more relational approach of the seventies and eighties, but now with a clear focus on forming disciples as a consequence of that relationship. Catholic youth ministry leaders research, examined later in this article, showed clearly this shift towards discipleship. When they were asked how they would define the purpose of their ministry, the majority $(65 \%)$ of participants responded, "forming disciples."14 Pope Francis, in Evangelii Guadium and Christus Vivit, takes it further by focusing not just on discipleship but missionary discipleship, where young people are not just recipients but agents of ministry, inviting their family and peers to faith. ${ }^{15}$

Pandemic Impact. It is uncertain how the pandemic will ultimately challenge the church and in what directions it will cause the pendulum to swing. Certainly, one element has been the move from in-person gatherings to more digital solutions. Many are wondering whether they will return to Church or when will things return to normal. Marti Jewell, a professor from the University of Dallas, stated recently, "Pastors have to let go of 'they will go back, and we'll do it as we did.'"16

Impact of the Pendulum Swings. Over the almost now 100 years of the history of Catholic youth and young adult ministry, especially in recent history, pastoral ministry leaders have been pushed and pulled in different directions as they try to respond to the needs of young people. The historical swings between programs and relationships, differing catechetical methods or strategies, doctrine versus discipleship, and varying purposes or focuses can leave pastoral leaders wondering what the best way is to respond and move forward. Catholic youth and young adult ministry has tried throughout its existence to respond to the needs of the time, which may be the cause of some of the swings,

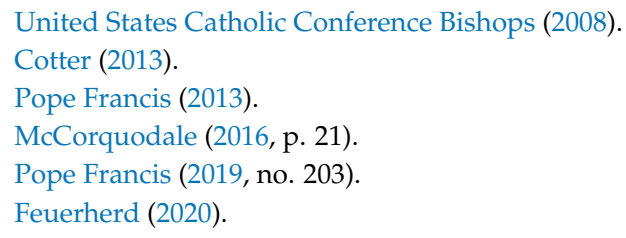


although different emphases by the USCCB and different Popes have also contributed. Now, with the pandemic and the expanding digital culture, it seems that this ministry is at another time where it is being pushed and pulled in a different direction. While guiding documents from the USCCB have played an important role in giving direction to the field, many times, these visions or goals have not been realized. Pope Francis' Christus Vivit, the first apostolic exhortation focused on pastoral ministry with youth and young adults, could have an influential role to play in the new directions for this ministry if it is properly analyzed and contextualized for our local settings.

\section{Research on Catholic Youth and Young Adult Ministry Leaders}

\subsection{Introduction to Youth Ministry Leader Research Scope and Methods}

Since 2000, I have conducted longitudinal research on youth and young adult ministry leaders. The purpose of this research has been to describe youth and young adult ministry leaders, including who they are, what they do, and how are they connected to the Church they serve ${ }^{17}$. The first study was conducted at the 2000 National Conference for Catholic Youth Ministry (NCCYM) ${ }^{18}$ in Birmingham, AL. It included a written survey with 58 questions, which was distributed to the entire population of conference participants. A sample size of 770 was used in the analysis, which included variables on formation, experience, practice, and professionalism.

The study was repeated in 2008 with a sample size of 935 and 2016 with a sample size of 1223 participants. In the two most recent studies, the survey was distributed also to youth and young adult ministry leaders from diocesan mailing lists via email and, in 2016, a Facebook group specific to Catholic youth ministry leaders. Paid or volunteer leaders serving in parishes, dioceses, and those who served the field through various ministries and movements were included.

The survey has always been only in English. The sample has relied heavily on participants of the NCCYMs. A couple of clear weaknesses in the sampling and methods of this study have been the inclusion of leaders who do not speak English limiting the diversity of the sample, or those who come from ministries that do not have the financial capabilities of participating in a national conference. The distribution to diocesan mailing lists and social media has broadened the sample but it still lacks the diversity of the field serving youth and young adults.

\subsection{Key Findings Regarding Youth and Young Adult Ministry Leaders}

Diversity Needed. Longitudinal research indicates that, since 2000, the pastoral ministry leaders with responsibility for youth and young adults have been made up primarily of lay Caucasian women in their early forties. Many demographics have remained consistent throughout the longitudinal study, although the recent study found that these leaders are becoming slightly more diverse in terms of gender, with $67 \%$ being female, and ethnicity, with $78 \%$ being Caucasian and only $12 \%$ being Hispanic. ${ }^{19}$ The Center for Applied Research in the Apostolate estimates that $38 \%$ of adult Catholics are Hispanic and approximately $10 \%$ of all lay ministers self-identify as Hispanic. It is clear that these ministry leaders do not reflect the cultural diversity of the Church, as noted in the conclusions of the research: "more needs to be done to foster youth ministry leaders that represent the Church served and to assure the research conducted reaches all youth ministry leaders." 20

Millennials Rising. The majority of all youth ministry leaders (38\%) are millennials and there were many areas in which they differed from earlier generations. ${ }^{21}$ Some of these areas include having the least amount of formal education, being paid significantly

17 McCorquodale (2016).

18 The NCCYM at the time was the only professional conference for Catholic youth ministry leaders. With no national database of these leaders, it was determined that this was an adequate sample for the field.

19 McCorquodale (2016, pp. 16-17).

20 ibid., p. 52.

21 ibid. 
less, and engaging parents in ministry less. Millennials were more likely than others to indicate that parental involvement in youth ministry was very significant; however, they were ironically also most likely not to include in their ministry parent/teen programs $(61 \%)$ and parent education programs (59\%). ${ }^{22}$ The study found that older generations of leaders see their ministry as a long-term commitment, with earlier studies noting that the most often stated reason for leaving ministry is to do another form of ministry. However, $43 \%$ of millennial leaders indicated that they planned to serve in youth ministry for five years or less, citing concerns about salary, benefits, and the time required to do the job. ${ }^{23}$ This should not be surprising since research on this generation finds that, when it comes to work, millennials change jobs frequently, seek financial security, and want a work-life balance. $^{24}$

The research concluded that, "While there is great hope with a surge of Millennials entering the field, their concerns about salary and benefits may prevent them from choosing ministry as a lifelong endeavor. ${ }^{25}$ " The impact of the lack of resources given to youth and young adult ministry both for staff and ministry efforts is a critical issue that is well-documented by research. ${ }^{26}$ As a Church, it will be important to find ways to address these issues so that continuity in leadership can be realized as the millennials who commit to ministry continue to rise in leadership.

\section{Research on Diocesan Directors of Youth and Young Adult Ministry}

\subsection{Introduction to Diocesan Director Research Scope and Methods}

The National Federation of Catholic Youth Ministry (NFCYM) has conducted longitudinal research on Diocesan Directors of Youth Ministry since 2000 and has repeated the study every five years through 2015. I have served as the lead researcher for the study since 2005. This survey research utilized the NFCYM list of Diocesan Directors of Youth Ministry or those in an equivalent role as the sample for the study. The number of questions on the survey varied from study to study; in 2015, there were 50 questions examining responsibilities, experience, education, professional practices, etc. The survey eventually moved online.

In recent years, the sample has included those responsible for young adult ministry at the diocesan level, since most who are responsible for youth ministry also have young adult ministry responsibilities. ${ }^{27}$ In the most recent study, Diocesan Directors of Pastoral Juvenil, those serving youth and young adults in the Hispanic community, were intentionally included in the sample, although they represent a small portion of the overall sample. It is important to note that the diversity of the responsibilities and titles related to this role has grown greatly over the course of the past 20 years. Because of this, it presents challenges in effectively defining and accessing a sample for this population of ministry leaders. ${ }^{28} \mathrm{New}$ strategies must be employed to better define the role and research audience.

\subsection{Key Findings Regarding Diocesan Directors of Youth and Young Adult Ministry}

Consistently Changing. Diocesan offices that oversee ministry to youth and young adults have experienced consistent change. The 2010 study found that $71 \%$ of offices had been expanded, subsumed into another office, re-organized, or closed, while in 2015-2016, that number dropped to $66 \%{ }^{29}$ The lack of consistent diocesan office structures and staff is a large part of the story of change for Catholic youth ministry. While many things contribute to financial challenges for dioceses, one of the most well-known would be the

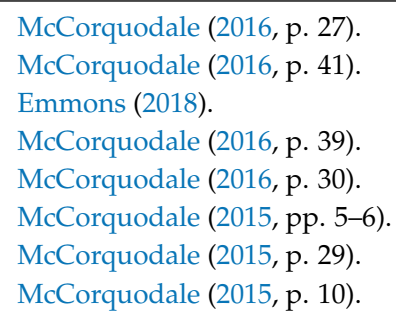


costs related to the sexual abuse scandals that have rocked the church since the mid-eighties through today. The number of arch/dioceses that have had to pay out settlements is welldocumented, often resulting in the need for arch/dioceses to file for bankruptcy and/or reorganize diocesan structures.

Multiple Ministries and Audiences. The trend in ministry responsibilities has been the combining of multiple ministries into one position at both the parish and diocesan levels. Over the past twenty years, at both the diocesan and parish levels, the age range of ministry responsibility has extended to middle school through young adults or 13 years old to 29, compared to 2000, when high school students were the main audience. ${ }^{30}$ The titles of youth ministry leaders reflect the expanding roles. In the 2000 study of Diocesan Directors of Youth Ministry, the vast majority held that title, but in 2015 , only $30 \%$ did. Current titles and responsibilities now often include young adult ministry, catechesis or evangelization, and family ministry. The broadening of ministerial responsibilities for these diocesan leaders may be one key reason that those in the study identified overwork and workplace stress as important issues.

Issues Impacting Diocesan Leaders. Diocesan youth ministry leaders indicated the top five issues impacting their ministry includes being overworked (89\%), the economy (72\%), work-related stress (71\%), lack of understanding about youth ministry (68\%), and polarization within Church and country (59\%). All five of these issues have been mentioned by $50 \%$ or more consistently throughout the life of this longitudinal look at the position. ${ }^{31}$ The pace of change and added responsibilities could be part of what is contributing to such high levels of work-related stress.

\section{New Directions from Christus Vivit}

In Christus Vivit, Pope Francis speaks both directly to the youth and to pastoral ministry leaders, giving broad and specific direction regarding the process of calling young people to missionary discipleship. In the exhortation, he indicates the current realities of many young people today and calls young people, parents, families, and the church to respond with open hearts and a sense of urgency to share God's mercy with all young people. $^{32}$ The exhortation is long and dense, full of insights and directions. One helpful resource, Christus Vivit: Pathways to Accompaniment, identifies ten themes that are woven throughout the apostolic exhortation. ${ }^{33}$ Below, I have listed each theme and a summary of what is being called for by Pope Francis when it comes to ministry with youth and young adults.

- $\quad$ Theme 1-The Holiness of the Young. We are called to celebrate the holiness and gift of being young, including their youthful presence in the Church. Moreover, the Church is called upon to embrace being "ever young" herself.

- $\quad$ Theme 2-The Spirit of Synodality. We are called to a spirit of Synodality that includes listening, discernment, dialogue, and collaboration. Listening and dialogue needs to becomes a primary stance in pastoral ministry with the young church.

- Theme 3-The Journey of Accompaniment. We are called to journey with young people, accompanying them through their many life issues and transitions, including vocational discernment and discernment in their daily lives. This process of accompanying includes helping young people to recognize their experiences, interpret them in light of the gospel, and make choices based upon their faith.

- Theme 4-The Now: Reality and Response. We are called to understand the lived experience and challenging realities faced by young people in today's world. In order for the Church to become relevant, it must not only understand these realities but respond to them.

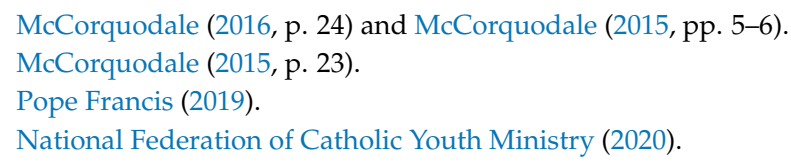


- Theme 5-The Gospel Message. We are called to proclaim the Gospel message of Christ and invite young people to encounter the Lord. The focal point of ministry should be deepening young people's relationship with Jesus.

- Theme 6-Pathways to Ministry. We are called to review and renew our current ministry efforts and acknowledge the shortcomings of current models, also trusting that the Holy Spirit will guide us in new directions and down new paths.

- Theme 7-The Wisdom of Generations. We are called to respond to the spectrum of early adolescents to young adults, including young parents with families. The goal is to enable all generations to grow together in faith, with older generations sharing the wisdom of their experience.

- Theme 8-The Call to Leadership. We are called to invite young people to become agents or the protagonist of the Church's pastoral ministry to the young. They are not only the recipients of ministry but entrusted to lead and become prophets of change for the Church and the world.

- $\quad$ Theme 9-An Invitation to Discernment. We are called to help the young discern how God is calling them both in everyday decisions and major decisions such as vocational ones. It is important that we accompany young people in this journey of discernment.

- Theme 10-Our Pathway to Mission. We are called to invite young people to share in Christ's mission to bring all people to himself, thus becoming missionary disciples. We must recognize that all are equipped and called to participate in Christ's mission.

\section{The Next Evolution of Ministry Leadership}

New Skills Needed. Beyond support for the ministry, leaders must evolve if the Church is to move in new directions with her pastoral ministry. While it is still unclear exactly how ministry roles will evolve post-pandemic, the experience of the pandemic and the research on ministry leaders point to a few things that ministry leaders must be able to do to lead in new directions:

- Work in a multi-ministry setting with abilities to serve a broad spectrum of age groups;

- Respond and lead change by continually evaluating their ministry efforts, and make necessary changes;

- Look beyond programs as a primary mode of ministry and towards relationships and accompaniment;

- Have skills in both accompanying youth and young adults directly, as well as empowering the faith community, families, and the young people themselves to join in that accompaniment;

- Integrate the use of current and emerging digital technologies with youth and young adult ministry efforts;

- Live as a missionary discipleship, first, then foster that in the people they minister to, and

- Teach about the faith using modern methods and be able to articulate faith relevance to the young church.

The most needed characteristics may well be flexibility and adaptability, which has been greatly exemplified throughout this current pandemic. It has challenged leaders at all levels of the Church to have to change in some way. The parish communities and ministry leaders that were able to pivot their face-to-face programs, meetings, and Masses to the virtual world found more success in navigating the pandemic. ${ }^{34}$ There is no doubt that faith communities will continue to be impacted by a changing world and the Church needs ministry leaders who can see the opportunity in the midst of crisis versus being stuck in wishing or waiting for things to return to normal.

New Structures Needed and More Support. But the responsibility is not just on ministry leaders, as the Church must renew her structures as well. With the emphasis on relationships and accompaniment rather than programs, finding ways to measure their 
success beyond analyzing program numbers will be key. Articulating clear realistic expectations will be essential for these ministry leaders with multiple audiences and areas of responsibility is essential. Identifying the new skills needed by ministry leaders is equally important, as well as the Church taking responsibility for the formation of these new skills. The Church needs to reimagine the ways in which these ministry leaders are formed. The trend towards multiple ministries being overseen by one person can easily be a trend that leads to burnout and frustration. Empowering ministry leaders to have flexible schedules, remote work at times, clear role descriptions, and measurement of ministry outcomes are all key to finding and keeping these leaders.

With financial resources dwindling, finding support for funding youth and young adult ministry adequately on both the diocesan and parish levels is critical. This was an issue prior to the pandemic but surely it has been exacerbated by it. It is common for most diocesan and parish planning processes to usually have ministry with youth as one of the top three priorities, but funding this priority adequately has been a challenge, especially in paying just salaries to those who lead this ministry. Convincing millennials and the new generation of emerging adults, Generation Z, that lay ecclesial ministry is a viable career and vocational option, especially when it comes to salaries, benefits, and ministry workload, will be one of the greatest challenges, only followed by keeping them.

\section{Moving in New Directions}

The history of pastoral ministry with youth and young adults shows a ministry that is ever-changing and responding to the needs of the time, some changes more successful than others. Throughout this history, there has been a need for the role of ministry leaders to be more fully integrated into the ministerial structures so that consistency can occur across parish and diocesan boundaries. ${ }^{35}$ Helping bishops and pastors to understand the new skills and roles needed and the ways to support them is critical to helping ministry leaders to evolve and be able to respond to changing times and in new directions.

The new directions needed in the Church's pastoral ministry with youth and young adults is clearly articulated by Pope Francis in Christus Vivit and the guiding Synod participants. If the church wants to move in these directions, it must evolve in its support for this ministry, and it must be substantial and unwavering. This includes focusing its energies on calling forth, forming, supporting, paying, and keeping those ministry leaders who themselves are willing to evolve to respond to changing times, as many in the history of this ministry have done. Finally, a new guiding document that contextualizes Christus Vivit for the United States needs to be developed to give direction to the future swings of the pendulum.

Funding: This research received no external funding.

Institutional Review Board Statement: Not applicable.

Informed Consent Statement: Not applicable.

Data Availability Statement: Not applicable.

Conflicts of Interest: The authors declare no conflict of interest.

\section{References}

Boorstein, Michelle. 2020. Catholic parishioners gave more money to churches that went online during the pandemic. The Washington Post. December 14. Available online: https:/ / www.washingtonpost.com/religion/2020/12/14/covid-coronavirus-shutdowncatholic-parish-offertory-giving-down/ (accessed on 14 December 2020).

Catholic Church. 2000. Catechism of the Catholic Church, 2nd ed. Washington, DC: United States Catholic Conference.

Cotter, Kevin. 2013. What is the New Evangelization? The Answer Might Surprise You. Focus. June 3. Available online: https:/ / focusequip. org/what-is-the-new-evangelization-the-answer-might-surprise-you/ (accessed on 3 June 2020).

35 McCorquodale (2016, p. 55). 
Emmons, Mark. 2018. Key Statistics about Millennials in the Workplace. Dynamic Signal. Available online: https://dynamicsignal. com/2018/10/09/key-statistics-millennials-in-the-workplace/\#: \{\}:text=Millennials\%20are\%20the\%20least \%20engaged, 16\%20percent $\% 20$ are \%20actively \%20disengaged.\&text=About $\% 2021 \% 20$ percent $\% 20$ of $\% 20$ Millennials,open $\% 20$ to $\% 20$ a $\% 20$ different\%20opportunity (accessed on 30 December 2020).

Feuerherd, Peter. 2020. Parishes must change post-pandemic, say authors of study. National Catholic Reporter. June 12. Available online: https:/ / www.ncronline.org/news/coronavirus/parishes-must-change-post-pandemic-say-authors-study (accessed on 12 June 2020).

Hoge, Dean. 1980. Social Factors Influencing Youth Ministry in the 1980's. In Hope for a Decade: A Look at the Issues Facing Catholic Youth Ministry. Washington, DC: National CYO Federation, Department of Education, U.S. Catholic Conference.

McCorquodale, Charlotte. 2015. Diocesan Youth Ministry Directors 2015: A Longitudinal National Portrait. Washington, DC: National Federation of Catholic Youth Ministry.

McCorquodale, Charlotte. 2016. Passing of the Baton in Catholic Youth Ministry: A National Longitudinal Study of Catholic Youth Ministry Leaders. Washington, DC: National Federation of Catholic Youth Ministry.

National Federation of Catholic Youth Ministry. 2020. Christus Vivit: The Pathway to Accompaniment. Washington, DC: National Federation of Catholic Youth Ministry.

Pontifical Council for the Promotion of the New Evangelization. 2020. Directory for Catechesis. Washington, DC: USCCB.

Pope, Charles. 2016. 4 Big Mistakes We've Made with Catechesis. National Catholic Register. March 14. Available online: https:/ /www. ncregister.com/blog/4-big-mistakes-weve-made-with-catechesis (accessed on 14 March 2016).

Pope Francis. 2013. Apostolic Exhortation Evangelii Gaudium. Washington, DC: United States Conference of Catholic Bishops.

Pope Francis. 2019. Post-Synodal Apostolic Exhortation Christus Vivit. Washington, DC: United States Conference of Catholic Bishops.

Roberto, John. 1980. Giving Direction to Youth Catechesis. In Hope for a Decade: A Look at the Issues Facing Catholic Youth Ministry. Washington, DC: National CYO Federation, Department of Education, United States Catholic Conference.

Saint Mary's Press in collaboration with the Center for Applied Research in the Apostolate. 2017. Going, Going, Gone: The Dynamics of Disaffiliation in Young Catholics. Winona: Saint Mary's Press.

Smith, Christian, and Melinda Lundquist Denton. 2005. Soul Searching: The Religious and Spiritual Lives of American Teenagers. New York: Oxford University Press.

United States Catholic Conference: Department of Education. 1976. A Vision for Youth Ministry. Washington, DC: USCCB Publishing.

United States Catholic Conference Bishops. 1996. Son and Daughters of the Light. Washington, DC: USCCB Publishing.

United States Catholic Conference Bishops. 1997. Renewing the Vision: A Framework for Catholic Youth Ministry. Washington, DC: USCCB Publishing.

United States Catholic Conference Bishops. 2008. Doctrinal Elements of a Curriculum Framework for the Development of Catechetical Materials for Young People of High School Age. Washington, DC: USCCB Publishing.

Weldgen, Francis. 1980. A Brief Look at the Growth of Catholic Youth Work in the United States. In Hope for a Decade: A Look at the Issues Facing Catholic Youth Ministry. Washington, DC: National CYO Federation, Department of Education, United States Catholic Conference. 